\title{
Forecast of magnitude post-subsidence compaction at the building on slow-subsidence of loess soils
}

\author{
Yuri Olyansky, Evgeniya Shekochihina and Sergey Kalinovsky* \\ Volgograd State Technical University (VSTU), Hydraulic and Earthwork Structures Department, \\ 400074, Akademicheskaya St. 1, Volgograd, Russian Federation
}

\begin{abstract}
Studies of loess subsidence soils under conditions of their longterm soaking and water filtration were performed. A set of predictive factors characterizing the composition and properties of loess soil responsible for its long-term deformation during soaking is revealed. A method of predicting the value of post-shrinkage compaction based on probabilistic analogies using the Bayes formula is proposed.
\end{abstract}

\section{Introduction}

Slow-subsidence soils include loess-like and loess-like medium and heavy loam, the dispersed component of which is represented mainly by montmorillonite [1]. Such loess soils are quite widespread in the territory of the Carpathians, Ciscaucasia, Volgograd and other regions of Russia [2,3].

The main problem of the control of subsidence on these soils follows from the fact that the current regulations (SP 22.13330.2016, GOST 23161-2012 [4,5]) provide for the determination of subsidence indicators: the value of the relative subsidence of the $\varepsilon_{\mathrm{sl}}$ and the initial subsidence pressure of the $\mathrm{P}_{\mathrm{sl}}$ in compression devices by short-term soaking of soil samples in conditions of their capillary water saturation. This test scheme is not fully consistent with the actual conditions of the bases and foundations, especially when flooding areas. For slow - subsidence soils, the difference in the values of subsidence indicators determined in the laboratory and on the basis of natural data is very significant, which is often the underlying cause of their deformations [6].

These are mainly medium loam soil $1.45-1.55 \mathrm{~g} / \mathrm{cm}^{3}$. The initial subsidence pressure is 0.11-0.12 MPa. The power of the loess layer varies in the range from 2-3 $\mathrm{m}$ to $25-30 \mathrm{~m}$. The thickness has a subsidence mainly to a depth of 11.0-12.0 m. Type of soil conditions on the subsidence of $80 \%$ of the city - I, and $20 \%$ of the territory - II. [7] The maximum drawdown of the thickness from its own weight reaches $20-25 \mathrm{~cm}$ (calculated according to compression tests according to the scheme of "two curves") [8].

\footnotetext{
* Corresponding author: sk0522@yandex.com
} 


\section{Methods}

Until 1962, during the construction on the subsidence soils of the city of Chisinau, only measures to protect the bases from soaking were carried out: the device of trays, inspection wells, blind areas, surface planning. A few years after the commissioning of houses began to bother the Foundation soils of faulty engineering networks. Water protection measures were ineffective and many of the constructed buildings began to deform, some of them were dismantled. Table 1 presents data on the determination of subsidence deformations of some samples of loess soils common in Chisinau $[9,10]$, which confirms the relevance of this problem.

Table 1. Indicators of relative deformation of some samples of loess rocks in the compression device at soaking and filtration of water for Chisinau.

\begin{tabular}{|c|c|c|c|c|}
\hline $\begin{array}{c}\text { № } \\
\text { sample's }\end{array}$ & $\begin{array}{c}\text { Failing } \\
\text { subsidence }\end{array}$ & $\begin{array}{c}\text { Slow } \\
\text { subsidence }\end{array}$ & $\begin{array}{c}\text { Post-subsidence } \\
\text { deformation }\end{array}$ & $\begin{array}{c}\text { General } \\
\text { relative } \\
\text { deformation }\end{array}$ \\
\hline 178 & 0.014 & 0.016 & 0.015 & 0.045 \\
\hline 314 & 0.042 & 0.005 & 0.037 & 0.084 \\
\hline 315 & 0.020 & 0.002 & 0.016 & 0.038 \\
\hline 316 & 0.017 & 0.008 & 0.021 & 0.046 \\
\hline 274 & 0.010 & 0 & 0.002 & 0.012 \\
\hline 226 & 0.022 & 0.004 & 0.034 & 0.060 \\
\hline 227 & 0.015 & 0.018 & 0.011 & 0.044 \\
\hline
\end{tabular}

The study of the deformation behavior of loess rocks was carried out in the compression devices of the system N. N. Maslova, allowing to measure subsidence deformation in capillary water saturation and the filtration of water through the soil specimen. Tap water was used. Compression tests were carried out by a "single curve" method with soaking at a load of $0.15 \mathrm{MPa}$. After conditional stabilization $(0.001 \mathrm{~mm}$ per 1 day), water filtration began within 90 days with daily registration of deformation. This method of compression tests, despite the well-known shortcomings, allows to evaluate not only the complete deformation of the sample during soaking, but also to differentiate it into the actual drawdown and post-shrinkage seal. It was widely used in the practice of research in the North Caucasus, Rostov region, Ukraine, Moldova, Central Asia. [8, 9, 11-14].

\section{Results and Discussion}

The change in mechanical composition is as follows. In General, the content of dispersed and fine fractions according to the results of microaggregate analysis has not changed. The greatest changes are noted for the fraction larger than $0.1 \mathrm{~mm}$. when water is filtered, these aggregates disintegrate, increasing the content of smaller fractions, which reduces the size of interaggregate pores and reduces the overall porosity. Aggregation of the dispersed fraction practically does not change, $\mathrm{K}_{\mathrm{agr}}=2.6-11.4$. As a result of long-term filtration and leaching of easily soluble salts, $\mathrm{Na}^{+}$content decreased by $1.5-3.0$ times, $\mathrm{Ca}^{+2}, \mathrm{Mg}^{+2}, \mathrm{Cl}-$, $\mathrm{SO}_{4}{ }^{-2}$ content increased significantly. The content of $\mathrm{HCO} 3$-has not changed much. As a result, the total mineralization either decreases by $20-30 \%$ or does not change at all, and in some cases increases by 1.7-1.8 times. To filter salinity type species was defined as: $\mathrm{Ca}^{+2}-$ $\mathrm{Mg}^{+2}-\mathrm{SO}_{4}^{-2}$ and $\mathrm{CO}_{3}^{-}$, following: $\mathrm{HCO}_{3}^{-}, \mathrm{Mg}^{+2}$ and $\mathrm{Ca}^{+2}$.

Tests of loess rocks under conditions of soaking and filtration during 90 days showed that long-term interaction with water leads to their complete degradation. The content of 
large fractions (more than $0.1 \mathrm{~mm}$ ) is reduced, due to them the content of smaller fractions is increased, with virtually no change in the content of the dispersed fraction. Easily soluble salts are washed out, at the same time weak and medium-soluble compounds are converted into highly soluble. Increases the content of hydrogen carbonates and gypsum, the soil takes on soda-soda or calcium magnesium salinity, becomes more dense and solid (as noted by E.N. Skvaletsky [14] for the rocks of Tajikistan is transformed into the "lake marl"). At the same time, almost all the properties of the loess change: $\mathrm{W}$ - increases by $0.05-0.12, \mathrm{~W}_{\mathrm{p}}$ does not change or increase by $0.01-0.02, \mathrm{~W}_{\mathrm{L}}$-increases by $0.01-0.04$, due to changes in the total content of carbonates, etc.as a result, Jp increases by $0.01-0.03$, porosity decreases, plastic strength decreases by 1.5-6.0 times.

The post-shrinkage seal associated with long-term filtration of water through loess rock is caused by the destruction of water-resistant structural colloidal bonds between its particles and manifests itself in the form of creep deformation of the skeleton. Subsidence and post-subsidence processes are usually combined and deformation is complex. Because of the difficulty of their differentiation in practice, they often speak about the General deformability of the loess layer, conditionally highlighting the most active flowing stage of the process (subsidence) and a smooth constantly damped (post- subsidence stage). Questions of quantification of both components are of great practical importance. During the experiment, the following values of the relative deformation were recorded:

$\varepsilon_{s l}^{2}$ - relative subsidence 2 days after soaking (on GOST 23161-2012);

$\varepsilon_{s l}^{4}$ - also, after 4 days after soaking (for A. Larionov, this is the time of completion of the failed subsidence);

$\varepsilon_{s l}^{k}$ - also after the completion of the sample consolidation during soaking;

$\varepsilon_{s l}^{\phi}$ - complete deformation of the sample after completion of water filtration.

The following components of the total deformation are calculated: $\varepsilon_{s l^{-}}^{4}$ failed subsidence (by A.K. Larionov); $\varepsilon_{s l}^{2}-\varepsilon_{s l}^{4}$ - slow subsidence; $\varepsilon_{s l}^{p}-\varepsilon_{s l}^{k}$-post-subsidence compaction. To predict the deformation of loess rocks during soaking and long-term filtration, the "coefficient of post-subsidence compaction", previously used by E. N. Skvaletsky $[14,15]$ and other researchers for loess rocks of the North Caucasus, Rostov region and Tajikistan.

The dependence of the coefficient of post-packing compaction on the composition and properties of the soil was studied. The results shown in table 2 show that the value of postseeding compaction depends on most indicators and primarily on the content of gypsum in loess soil, aggregation of the dispersed fraction and density of dry soil. However, the correlation coefficient of these indicators with the coefficient of post-shrinkage compaction is not high enough and does not exceed the value of 0.85 [16]. It does not allow to make a forecast on the revealed correlation dependences. For a qualitative forecast, you can use the method of multivariate correlation analysis, or any other, allowing you to simultaneously take into account several predictive factors. Taking into account that the volume of completed studies is large enough and amounts to 100 samples, the method of probabilistic analogies can be used to predict the value of the post-packing compaction. Previously, all samples according to the value of the coefficient of the post-packing seal are divided into 5 groups: $1.0-1.3 ; 1.3-1.7 ; 1.7-2.2 ; 2.2-3.0$; more than 3.0 . six different indicators are proposed as predictive factors, which fully reflect the composition, condition and properties of loess rocks. 
Table 2. The regression dependence of the coefficient post-subsidence compaction $\mathrm{K}_{\mathrm{pc}}$ from the indicators of the composition and properties of loess rocks

\begin{tabular}{|l|c|c|}
\hline \multicolumn{1}{|c|}{$\begin{array}{c}\text { The indicators of composition } \\
\text { and properties }\end{array}$} & Regression equation & $\begin{array}{c}\text { Coefficient } \\
\text { correlations }\end{array}$ \\
\hline Gypsum content $\mathrm{G}, \%$ & $\mathrm{~K}_{\mathrm{pc}}=25.243 \mathrm{G}+1.103$ & 0.85 \\
\hline $\begin{array}{l}\text { The density of the dry } \\
\text { soil's }-\rho_{d}, \mathrm{~g} / \mathrm{cm}^{3}\end{array}$ & $\mathrm{~K}_{\mathrm{pc}}=3.5495 \mathrm{Pd}-3.3509$ & 0.81 \\
\hline $\begin{array}{l}\text { Coefficient } \\
\text { the aggregation of dispersed } \\
\text { fractions }-\mathrm{K}_{\mathrm{agr}}\end{array}$ & $\begin{array}{c}\mathrm{K}_{\mathrm{pc}}=0.0009 \mathrm{~K}_{\mathrm{agr}}{ }^{2}- \\
-0.0406 \mathrm{~K}_{\mathrm{agr}}+1.6846\end{array}$ & 0.73 \\
\hline $\begin{array}{l}\text { Content } \\
\text { montmorillonite in } \\
\text { dispersed fraction }-\mathrm{M}, \%\end{array}$ & $\mathrm{~K}_{\mathrm{pc}}=0.0218 \mathrm{M}+1.1909$ & 0.71 \\
\hline $\begin{array}{l}\text { Relative magnitude } \\
\text { the subsidence } \varepsilon_{\mathrm{sl}} \\
\text { (on GOST } 23161-2012)\end{array}$ & $\mathrm{K}_{\mathrm{pc}}=294.94 \varepsilon_{s l}^{2}-30.047 \varepsilon_{s l}$ & 0.55 \\
\hline $\begin{array}{l}\text { Trivalent iron }-\mathrm{F}, \\
\text { g/100 g. rock }\end{array}$ & $\mathrm{K}_{\mathrm{pc}}=1.1173 \mathrm{~F}+1.4762$ & 0.54 \\
\hline Yield strength $-\mathrm{W}_{\mathrm{L}}$ & $\mathrm{K}_{\mathrm{pc}}=6.4276 \mathrm{~W}_{\mathrm{L}}-0.1589$ & 0.50 \\
\hline $\begin{array}{l}\text { Content of exchange } \\
\text { calcium's }-\mathrm{C}, \\
\text { mg-eq } / 100 \mathrm{~g} \text { rock }\end{array}$ & $\mathrm{K}_{\mathrm{pc}}=0.1331 \mathrm{C}+1.7814$ & 0.40 \\
\hline $\begin{array}{l}\text { Total content } \\
\text { dispersed fraction } \mathrm{D}, \%\end{array}$ & $\mathrm{~K}_{\mathrm{pc}}=2.6407-0.0134 \mathrm{D}$ & 0.33 \\
\hline
\end{tabular}

For the determination of subsidence seal area, similar to calculated the empirical estimate of the probability of prognostic factors and quasi-a priori probability (table.3). The calculation of the coefficient can be carried out using Bayes' theorem, which is formed as follows. Let $A_{1}, A_{2} \ldots A_{j}$ - pairwise incompatible events, at least one of which is sure to come, $B_{i}$ - some events. Then the probability of realization of events $A_{j}$, provided that there will be an event $B_{i}$, is expressed by the formula:

$$
\left.P_{A_{j} / B_{j}}\right)=\frac{\left.P_{A_{j}}\right) \stackrel{n}{\prod_{i=1}^{n} \cdot P_{\left(B_{i} / A_{j}\right)}}}{\left.\left.\sum_{j=1}^{m} P_{A_{j}}\right) \cdot \prod_{i=1}^{n} P_{\left(B_{i} / A_{j}\right.}\right)}
$$

where:

$P_{\left(A_{j} / B_{j}\right)}$ - conditional probability of an event $\mathrm{A}_{\mathrm{j}}$ at the actual occurrence of the event $\mathrm{B}_{\mathrm{i}}$;

$\left.P_{B_{i} / A_{j}}\right)^{-}$probability of realization of the event at the given $\mathrm{B}_{\mathrm{i}}$ with this $\mathrm{A}_{\mathrm{j}}$;

$\left.P_{A_{j}}\right)^{-}$a priori probability of occurrence $\mathrm{A}_{\mathrm{j}}$.

Table 4 shows the results of calculation of the coefficients of post-subsidence compaction for loess soils of engineering-geological regions of Northern, Central and Southern Moldova. More clay group North of the country have greater value post-1 subsidence compaction.

Figure 1 shows graphs of dependence of the coefficient of post-subsidence compaction the $\mathrm{K}_{\mathrm{pc}}$ from the density of dry soil $\rho_{d}(a)$, content of gypsum $\mathrm{G}(b)$, coefficient of aggregation of the disperse fraction $\mathrm{K}_{\mathrm{agr}}(c)$. 
Table 3. Empirical estimates of the probabilities of predictive factors $\left.P_{\left(B_{i} / A_{j}\right.}\right)$ in calculating the coefficient of post-subsidence compaction

\begin{tabular}{|c|c|c|c|c|c|}
\hline \multirow{2}{*}{ Predictive factors } & \multicolumn{5}{|c|}{ Coefficient of post- subsidence compaction $K_{p c}$} \\
\hline & $1,0-1,3$ & $1,3-1,7$ & $1,7-2,2$ & $2,2-3,0$ & more than 3,0 \\
\hline $\begin{array}{l}\text { The content of the dispersed } \\
\text { fraction-D, } \% \\
\text { less than } 30 \\
30-50 \\
\text { more than } 50\end{array}$ & 0.04 & $\begin{array}{l}0.04 \\
0.20 \\
0.04\end{array}$ & $\begin{array}{l}0.04 \\
0.26 \\
0.08\end{array}$ & $\begin{array}{l}0.08 \\
0.14 \\
0.04\end{array}$ & 0.04 \\
\hline $\begin{array}{l}\text { Coefficient the aggregation of } \\
\text { dispersed factions }-\mathrm{K}_{\text {agr }} \\
\text { less than } 20 \\
\text { more than } 20\end{array}$ & $\begin{array}{l}0.08 \\
0.04\end{array}$ & $\begin{array}{l}0.16 \\
0.04\end{array}$ & $\begin{array}{l}0.24 \\
0.12\end{array}$ & 0.28 & 0.04 \\
\hline $\begin{array}{l}\text { Yield strength }-\mathrm{W}_{\mathrm{L}} \\
\text { less than } 0.28 \\
0.28-0.32 \\
\text { more than } 0,32\end{array}$ & 0.08 & $\begin{array}{l}0.16 \\
0.12 \\
0.04\end{array}$ & $\begin{array}{l}0.04 \\
0.20 \\
0.08\end{array}$ & $\begin{array}{l}0.08 \\
0.12\end{array}$ & \\
\hline $\begin{array}{l}\text { Density of dry soil }-\mathrm{p}_{\mathrm{d}}, \mathrm{g} / \mathrm{cm}^{3} \\
\text { less than } 1.40 \\
1.40-1.60 \\
\text { more than } 1.60\end{array}$ & $\begin{array}{l}0.07 \\
0.03\end{array}$ & $\begin{array}{l}0.10 \\
0.13\end{array}$ & $\begin{array}{l}0.03 \\
0.28 \\
0.03\end{array}$ & $\begin{array}{l}0.10 \\
0.17\end{array}$ & $\begin{array}{l}0.03 \\
0.03\end{array}$ \\
\hline $\begin{array}{l}\text { Relative magnitude } \\
\text { the subsidence }-\varepsilon_{s l} \\
\text { (on GOST 23161-2012) } \\
\text { less than } 0.01 \\
0.01-0.02 \\
\text { more than } 0.02\end{array}$ & $\begin{array}{l}0.10 \\
0.02\end{array}$ & $\begin{array}{l}0.02 \\
0.12 \\
0.10\end{array}$ & $\begin{array}{l}0.12 \\
0.14 \\
0.05\end{array}$ & $\begin{array}{l}0.17 \\
0.05 \\
0.02\end{array}$ & $\begin{array}{l}0.07 \\
0.02\end{array}$ \\
\hline $\begin{array}{l}\text { Gypsum content - G, \% } \\
\text { less than } 0.02 \\
\text { more than } 0.02\end{array}$ & 0.11 & $\begin{array}{l}0.22 \\
0.17\end{array}$ & $\begin{array}{l}0.11 \\
0.22\end{array}$ & 0.17 & \\
\hline Quasi-a priori probability - $\mathrm{P}_{(\mathrm{Aj})}$ & 0.08 & 0.21 & 0.32 & 0.26 & 0.13 \\
\hline
\end{tabular}

Table 4. Magnitude of the coefficients of the post-subsidence compaction $\mathrm{K}_{\mathrm{pc}}$ for regions of Moldova

\begin{tabular}{|l|c|c|}
\hline \multicolumn{1}{|c|}{ Values of predictive factors } & $\begin{array}{c}\text { Northern } \\
\text { Moldova, } \\
\text { Soroca }\end{array}$ & $\begin{array}{c}\text { Central } \\
\text { Moldova, } \\
\text { Chisinau }\end{array}$ \\
\hline The content of dispersed fractions - D, \% & 59.93 & 34.56 \\
\hline The coefficient of aggregation of the disperse fraction $-\mathrm{K}_{\text {agr. }}$ & 2.8 & 2.7 \\
\hline Yield strength - $\mathrm{W}_{\mathrm{L}}$ & 0.43 & 0.28 \\
\hline The density of dry soil $-\rho_{d}, \mathrm{~g} / \%$ & 1.49 & 1.60 \\
\hline The relative subsidence on GOST $23161-2012$ & 0.008 & 0.015 \\
\hline Gypsum content $-\mathrm{G}, \%$ & 0.006 & 0.15 \\
\hline Coefficient of post-subsidence compaction $-\mathrm{K}_{\mathrm{pc} .}$ & $2.2-3.0$ & $1.7-2.2$ \\
\hline Probability - $\mathrm{P}_{\mathrm{i},} \%$ & 62.2 & 92.1 \\
\hline
\end{tabular}




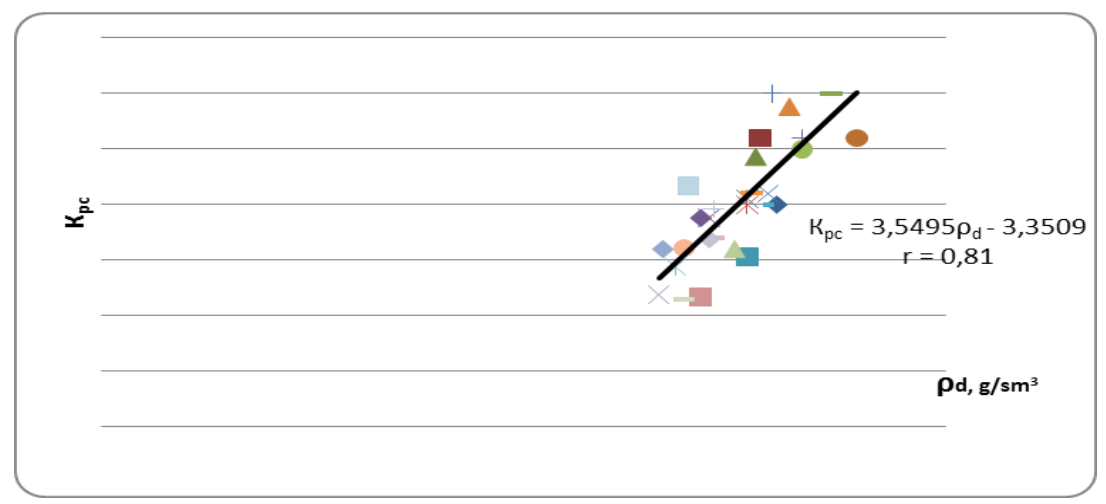

(a)

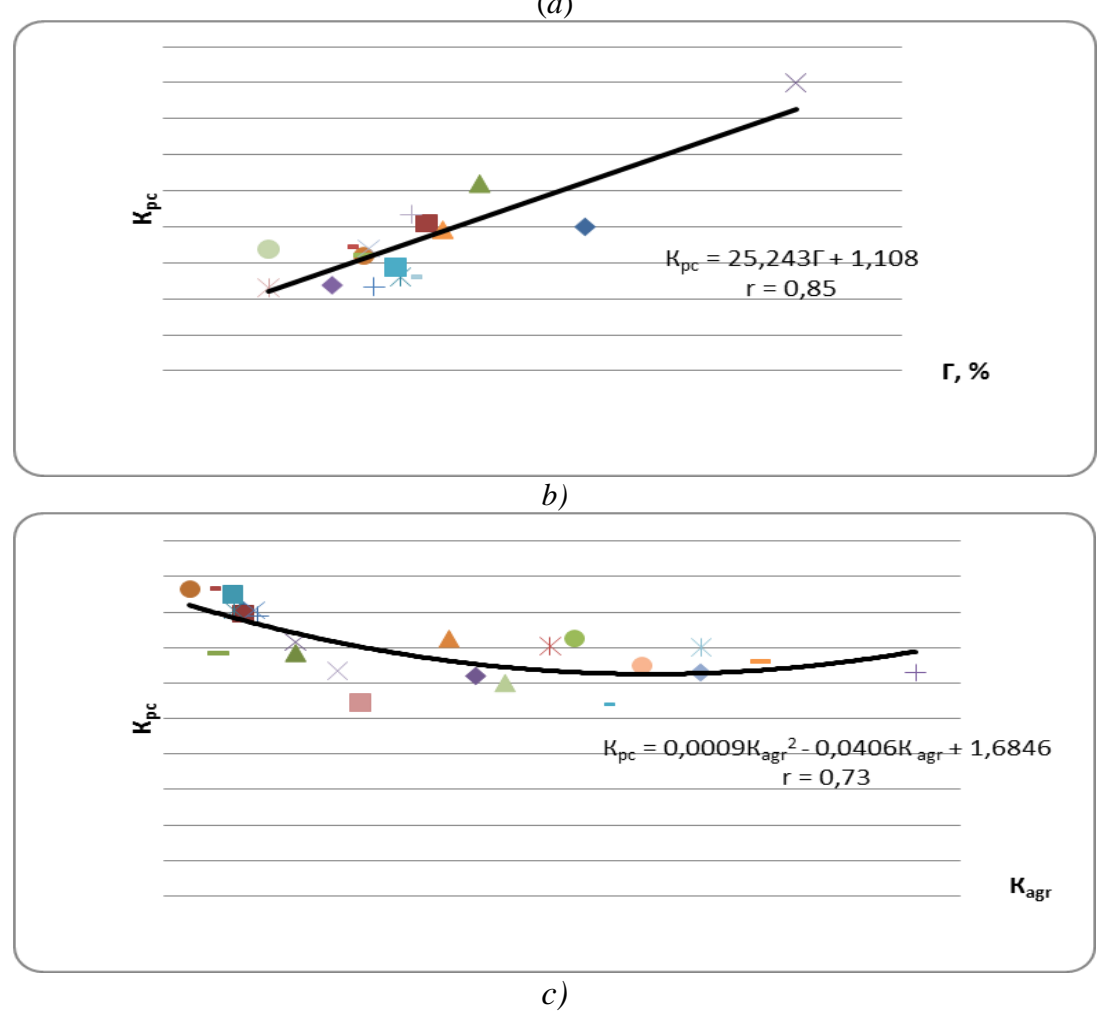

Fig. 1. Graphs of dependence of the coefficient of post-subsidence compaction the $K_{\mathrm{pc}}$ from the density of dry soil $\rho_{d}(a)$, content of gypsum $\mathrm{G}(b)$, coefficient of aggregation of the disperse fraction $\mathrm{K}_{\mathrm{agr}}(c)$.

\section{Conclusions}

This method of determining the total deformation of loess subsidence soils during their long-term interaction with water under filtration conditions can be used in the early stages of engineering-geological surveys for the design stages: General plan and technical design of structures. Application of the above-described technique to different types of loess soils in any territory will help to predict the behavior of such soils as the grounds and reduce the accident rate of subsequently constructed structures. 


\section{References}

1. B.F. Galai, B.B. Galai. The loess of the USA and the North Caucasus (Comparative analysis). Newsletter of North-Caucasus Federal University. № 1. 25-29 (2009)

2. V.I. Osipov, V.I. Larionov, V.N. Burova, N.I. Frolova, S.P. Sushchev. Methodology of natural risk assessment in Russia. Natural Hazards, 2017. 88 № 1. 17-41 (2017)

3. V.I. Osipov, V.N. Burova, E.A. Karfidova. Methodological principles of geo-hazard vulnerability evaluation of capital construction assets in urbanized areas. Soil Mechanics and Foundation Engineering, 53. № 6. 420-425 (2017)

4. SP 22.13330.2016 Foundations of buildings and structures. Updated version of SNiP 2.02.01-83* 166 p. (Ed. Standartinform, Moskow, 2017)

5. GOST 23161-2012 Soils. Laboratory method for determining the characteristics of the subsidence. Interstate standard. 13 p. (Ed. Standartinform, Moskow, 2013)

6. B.F. Galai, V.V. Serbin, V.S. Plakhtyukova, O.B. Galai. Criticisms to the provisions of the regulations on the assessment of subsidence of loess soils according to their physical characteristics. Engineering research, № 14. 18-23 (2016)

7. A.N. Bogomolov, Y.I. Olyansky, L.A. Anisimov, E.V. Schekochikhina, A.F. Alekseev. Preparation of the bases of buildings and constructions, built at the slowly - subsiding soils type I and II according to the subsidence. Vestnik of Volgograd State University of Architecture and Construction. Series: Constr. and archit., 41 (60). 14-23 (2015)

8. E.V. Zaporozhchenko, S.V. Trusova. On the degree of compaction of loess rocks during long-term filtration of water through them. Abstracts at the all-Union conference. Rostov-on-Don. 109-113 (1980)

9. Y.I. Olyansky, O.P. Bogdevch, V.M. Vovk. About additional consolidation of some types of loess breeds of Moldova at water filtration. News of Academy of Sciences of the Moldavian SSR. Physics and technology. (1991)

10. Y.I. Olyansky, S.A. Kalinovsky. Features of construction of buildings and constructions on loessial the bases in Moldova, IOP Conf. Ser.: Mat. Sci. Eng., 365 (6), 062034 (2018), DOI: 1088/1757-899X/365/6/062034

11. N.A. Oknina, K.S. Reutova, N.G. Inozharskaya, The changes of engineeringgeological properties of loess rocks of the Danube-Dniester irrigation of the array under the influence of long filter. Complex engineering-geological evaluation of clay loess rocks. Works PNIIIS. vol. XII 150-164 (Ed. Stroyizdat, Moskow, 1971)

12. Y.I. Olyansky Loess soils of South-Western Black sea within the Republic of Moldova. 130p. (Scienza, Chisinau 1992)

13. A.N. Bogomolov, Y.I. Olyansky, E.V. Schekochikhina, T.M. Tikhonova, I.Y. Kuzmenko, Changes in the composition and properties of loess rocks in the man-made watering. 204p. (Ed. VolgGASU: Volgograd, 2015)

14. E.N. Skvaletsky Engineering-geological prediction and protection of the natural environment. Dushanbe 259 p. (Ed. "Donish", 1988)

15. N.I. Kriger Loess. Formation subsidence properties. 133 p. (Ed. Nauka, Moscow, 1968)

16. A.N. Bogomolov, Y.I. Olyansky Engineering-geological aspects of the interaction of clay rocks with water in technogenesis (on the example of Sarmatian clays and loess rocks) 357p. (Ed. VolgGASU, Volgograd, 2016) 